\title{
Performance of zephyr board made from various rolling crush Number and palm oil petiole parts
}

\author{
Lusita Wardani ${ }^{1, ~ *, ~ M a s s i j a y a ~ M u h a m a d ~ Y u s r a m ², ~ Y u s u f ~ S u d o ~ H a d i ², ~ D a r m a w a n ~ I . ~ W a y a n ~}{ }^{2}$ \\ ${ }^{1} \mathrm{PhD}$ Student of Forest Product Technology, Bogor Agricultural University, Bogor,Indonesia \\ ${ }^{2}$ Lecturer of Forestry Faculty, Bogor Agricultural University, Bogor, Indonesia
}

\section{E-mail address:}

lusita41@yahoo.com (L. Wardani)

\section{To cite this article:}

Lusita Wardani, Massijaya Muhamad Yusram, Yusuf Sudo Hadi, Darmawan I. Wayan. Performance of Zephyr Board Made From Various Rolling Crush Number and Palm Oil Petiole Parts. Agriculture, Forestry and Fisheries. Vol. 3, No. 2, 2014, pp. 71-75.

doi: 10.11648/j.aff.20140302.14

\begin{abstract}
The objective of this research was to evaluate physical and mechanical properties of zephyr board made from palm oil petiole parts. The palm oil petiole parts were distinguished on the basis of rolling crushed number (4, 5 and 6 times, as factor A) and base, middle and upper parts of petiole (factor B). The board was made from three layers of petiole with density of $0.75 \mathrm{~g} . \mathrm{cm}^{-3}$ and thickness $1 \mathrm{~cm}$ respectively using Phenol formaldehyde (PF) with $12 \%$ resin as binding agent and compressed the board at $120^{\circ} \mathrm{C}$ temperature and $25 \mathrm{~kg} / \mathrm{cm}^{-2}$ pressure for 10 minutes. The results showed that physical properties of a zephyr board included of density, moisture content (MC), water absorption (WA), and thickness swelling (TS) were 0.74 g. $\mathrm{cm}^{-3}, 12.32 \%, 29.14 \%, 5.19 \%$, respectively. Mechanical properties such as modulus of elasticity (MOE), modulus of rupture (MOR), screw with drawl (SW) were $44.7 \times 10^{3} \mathrm{kgf. \textrm {cm } ^ { - 2 } , 2 6 8 \mathrm { kgf.cm }}{ }^{-2}, 107.32 \mathrm{kgf}$, respectively. In generally, number of rolling crushed was affected to moisture content, water absorption and MOR value whereas petiole part was significantly affected to MOR value only. Some of properties zephyr boards made from oil palmpetiole fulfill JIS A 5908-2003 standard.
\end{abstract}

Keywords: Palm Oil Petiole, Crushed Number, Petiole Part, Zephyr Board

\section{Introduction}

Ligno-cellulosic materials form palm oil petiole that can be used for zephyr board or other bio-composite materials. The size of petiole is very promising to be utilized as alternative material for zephyr board. For the information, production of palm oil petiole waste from plantation was about 10.4 tones / ha / year [1].

The age of petiole is only 8 month ready to trim to a length of 5 meters with dimension of base width $10-17 \mathrm{~cm}$ and thickness of $7 \mathrm{~cm}$ to upper part width of base $1.5-2.0$ $\mathrm{cm}$ and thickness of $2-3 \mathrm{~cm}$. petiole base must be hard and thick than other parts of petiole [2].

Zephyr, sheet material of fibrous net-like sructure prepared similar to scrimber. The proces involves progresive chrushing of materials through several sets of rolers until a continuous fibrous shett is obtained,3]. [4] reported that zephyr board was used for wall seperations in the main building by using Phenol formaldehyde (PF) resin. The voids and surface roughness were the main problem in improving the strength of zephyr board. The strength of Zephyr board was improved with with the increasing density and decreasing dimension of fiber. Small fibers $(1.5$ and $2.8 \mathrm{~mm})$ had a great compaction ratio and smoothness surface as compared to long fiber (4.7 and $9.5 \mathrm{~mm})[5]$.

Bamboo zephyr board (BZB) which reinforcement can be use for wood structural panels [6]. Lee [7] was conducted to evaluate the properties of LBL, quasiflattened maso bamboo (using colg press at $640 \mathrm{kPa}$, or about $70 \mathrm{kgf} / \mathrm{cm}^{2}$ for 1 to 4 minutes) was laminated to from compiste that is similar in contruction to that of LVL. Their research indicated that LBL had superior strength property compared to wood-based LVL as indicated by its higher MOR[7]. Kim [8] , also explored a research regarding the poduction of zephyr strand board (ZSB) and zephyr strand lumber (ZSL) using zephyr made from poplar veneer. They found that the bending strength properties of ZSB provide superior to those of poplar plywood, and ZSL produced from poplar veneer zephyr had bending properties greater than ordinary LVL

Zephyr board was using for wall separations in the main 
building by using Phenol Formaldehyde (PF) resin[9]. The voids and surface roughness were the main problem in improving the strength of zephyr board. The strength of zephyr board was improved with the increasing density and decreasing dimension of fiber. [3]

The efforts are on to improve the quality of zephyr boards in order to develop wood panel industry in the region. Palm petiole can be considered as alternative material for zephyr boards because it straight and long without any node and has high potency.P the petiole has different density from base, middle and upper that were $0.47 ; 0.44$ and $0.27 \mathrm{~g} / \mathrm{m}^{-3}$ with hardness of $176 \mathrm{~kg} . \mathrm{cm}^{-2}$, $166 \mathrm{~kg} . \mathrm{cm}^{-2} ; 120 \mathrm{~kg} . \mathrm{cm}^{-2}$. The modulus of elasticity(MOE) were $3605-2 ; 3967 \mathrm{~kg} . \mathrm{cm}^{-2} ; 1629 \mathrm{~kg}$. $\mathrm{cm}^{-2}$ and modulus of rupture(MOR) were $110.6-2 \mathrm{~kg} . \mathrm{cm}^{-2} ; 103.3 \mathrm{~kg} . \mathrm{cm}^{-2} ; 64.3$ $\mathrm{kg} . \mathrm{cm}^{-2} \cdot[10]$

this research was undertaken to evaluate the performance of zephyr board, made from different rolling crushed number and parts of petiole of palm tree. $r$

\section{Materials and Method}

10 year old Palm Petiole was cut into 3 parts such as base, middle and upper (factor B), and petiole treated as number of rolling crushed comprise 4, 5 and 6 times (factor A). Zephyr strands was dried up to $10 \%$ moisture content. Three layers of zephyr sheet $(30 \mathrm{~cm}$ length x $30 \mathrm{~cm}$ width) was arranged with density of $0.75 \mathrm{~g} . \mathrm{cm}^{-3}$ and thickness of 1 $\mathrm{cm}$, respectively. Amount 10\% phenol formaldehyde (PF) resin was used as binding agent. Furthermore, furnish was pressed at $120^{\circ} \mathrm{C}$ temperature for 10 minutes and compressed at $25 \mathrm{kgf. \textrm {cm } ^ { - 2 }}$ pressure. Physical properties (density, MC, WA, and TS), and mechanical properties (MOR, MOE and SW) were evaluated according to Japan Industrial Standard Ascociation [JIS A 5908-2003 [11]] standard for particle board.

The flow chart of process zephyrboard as show in Fig.1

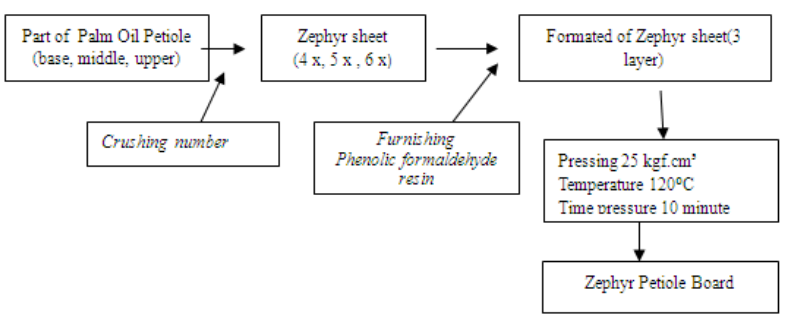

Figure 1. Flow chart processing of zephyr board

\subsection{Data Analysis}

Two factors of a completely randomized design in 3 replicates were used in this experiment. Data analysis was conducted using SPSS software. Significant difference $(\alpha<0.05$ or $\alpha<0.01)$ between mean values of temperature, time and interaction of both were determined using duncan's multiple range tests (DMRT).

\section{Results and Discussion}

\subsection{The Physical Properties of Zephyr Board}

Physical properties of zephyr board such as density, moisture content (MC), water absorption(WA) for 24 hours and thickness of swelling(TS) for 24 hours showed in Table 1.

Table 1. The value of density, moisture content, water adsorbtion and thickness swelling of zephyr boards

\begin{tabular}{|c|c|c|c|c|c|}
\hline Treatment & Petiole part & Density $\left(\right.$ g.cm $\left.{ }^{-3}\right)$ & MC (\%) & WA(\%) & TS(\%) \\
\hline \multirow{3}{*}{ Crushed 4 times } & Base & 0.74 & 13.56 & 22.10 & 5.52 \\
\hline & Middle & 0.77 & 12.38 & 16.01 & 5.90 \\
\hline & Upper & 0.70 & 12.24 & 16.01 & 4.59 \\
\hline \multirow{3}{*}{ Crushed 5 times } & Base & 0.70 & 11.51 & 38.21 & 4.28 \\
\hline & Middle & 0.72 & 12.34 & 36.51 & 4.31 \\
\hline & Upper & 0.81 & 12.08 & 32.68 & 5.84 \\
\hline \multirow{3}{*}{ Crushed 6 times } & Base & 0.72 & 12.41 & 59.79 & 6.19 \\
\hline & Middle & 0.72 & 12.22 & 22.93 & 6.39 \\
\hline & Upper & 0.82 & 12.22 & 18.06 & 3.68 \\
\hline JIS A 5908-2003 Type 18 & & $0.40-0.90$ & $5-13$ & $<20$ & $<12$ \\
\hline
\end{tabular}

Table 2. Variance analysis of zephyr board physical properties

\begin{tabular}{|c|c|c|c|c|c|c|c|c|}
\hline \multirow{2}{*}{ Roller crusher(check spelling ) } & \multicolumn{2}{|l|}{ Density } & \multicolumn{2}{|l|}{ MC } & \multicolumn{2}{|l|}{ WA } & \multicolumn{2}{|l|}{ TS } \\
\hline & $\mathbf{F}$ & $\mathbf{P}$ & $\mathbf{F}$ & $\mathbf{P}$ & $\mathbf{F}$ & $\mathbf{P}$ & $\mathbf{F}$ & $\mathbf{P}$ \\
\hline A (Crushed) & 0.82 & $0.46 \mathrm{~ns}$ & 4.84 & $0.021 *$ & 3.96 & $0.037 *$ & 0.28 & $0.766 \mathrm{~ns}$ \\
\hline B(Petiole part) & 0.46 & $0.64 \mathrm{~ns}$ & 0.64 & $0.54 \mathrm{~ns}$ & 0.80 & $0.46 \mathrm{~ns}$ & 0.49 & $0.621 \mathrm{~ns}$ \\
\hline $\mathrm{AB}$ (Interaction $\mathrm{AB})$ & 0.61 & $0.66 \mathrm{~ns}$ & 1.23 & $0.33 \mathrm{~ns}$ & 0.08 & $0.987 \mathrm{~ns}$ & 1.30 & $0.307 \mathrm{~ns}$ \\
\hline $\mathrm{sd}$ & $7.33 \%$ & & $7.33 \%$ & & $50.31 \%$ & & $30.42 \%$ & \\
\hline
\end{tabular}

$\mathrm{ns}=$ no significant effect $(\mathrm{P}>0,05) *=$ significant effect $(\mathrm{P} \leq 0,05)$

The density of zephyr boards was varied from 0.70 to 0.82 g. $\mathrm{cm}^{-3}$ and those was classified into medium density of board. Statistical analysis showed that analysis of varianc on the crushed number and petiole part were not significantly different to affect board density. The density value is within the range of $\left(0.4\right.$ to $\left.0.9 \mathrm{~g} \cdot \mathrm{cm}^{-3}\right)$. JIS2003The zephyr 
dimension with different crushed number showed relative homogen after drying. It can be explained because zephyr sheet loose water content, so that the fiber broken and separated. The average value of density based on petiole position from base, middle and upper were $0.73 \mathrm{~g} . \mathrm{cm}^{-3} ; 0.76$ g.cm ${ }^{-3}$ and 0.79 g.cm ${ }^{-3}$. It not significantly different in density value, but upper part showed high value compared to other. Upper petiole have lower basic density, small and thin fiber, homogen and more soft than lower and middle. This condition caused zephyr sheet from crushed process more homogen and resulted higher density zephyr board.

The highest value of MC obtained from base petiole board with 4 times rolling crushed whereas other treatment have relatively same value. Statistical analysis using DMRT showed that crushed number significantly influence MC value (Table 3 ).

Table 3. The effect of rolling crushed number to moisture content using DMRT test

\begin{tabular}{cc}
\hline Roller (Check spelling) & MC \\
\hline 4 time & $13.40^{*}$ \\
5 time & 11.97 \\
6 time & 12.28 \\
\hline
\end{tabular}

Note: * significant at $\alpha=0.05$

Base petiole treated with 4 time crushed causing have bigger and less homogenous fiber than other. Result of thickness measurements from different crushed number those were 0.7-9.9 mm;0.1-7.57 mm; and 0.1-6.22 mm. The thickness and hardness of base petiole presumed causing non homogenous of zephyr fiber so that zephyr board containing different water volume. Moisture content of zephyr board resulted in this research range from 11.51 to $12.41 \%$ and still fulfill JIS A 5908-2003 standard.

Water absorbsion of zephyr board wasthe quality of board. Zephyr board from lingo-cellulosic material have several weakness related to it natural properties that was easy to absorb water. Research showed zephyr boards have WA value 13.85 to $59.76 \%$ after 24 hour of immersion in water. The number of rolling crushed significantly affected WA. Result of DMRT test presented in Table 4.

Table 4. DMRT test of effect number of rolling crusher factor to water absorbsion properties

\begin{tabular}{cc}
\hline Roller (check spelling) & WA \\
\hline $4 \mathrm{x}$ & $18.04 \mathrm{a}$ \\
$5 \mathrm{x}$ & $35.80 * \mathrm{~b}$ \\
$6 \mathrm{x}$ & $23.84 \mathrm{a}$ \\
\hline
\end{tabular}

Description: superskrips with the same letter indicates not significantly different by DMRT at level of $\alpha=0.05$

Based on Table 4, rolling crusher for 5 times have different value. Petiole of palm oil have number of vascular bundles approximatelly $16-18 / \mathrm{mm}^{2}$, it mean that the petiole have undenser vascular and easy to absorp water. Density value of petiole from base to upper were classified into lower class $\left(0.27\right.$ to $\left.0.46 \mathrm{~g} . \mathrm{cm}^{-2}\right)$ [12]. The effect of crushed number to water absorptionesumed related with zephyr fiber dimension and part of petiole. To solved this problem, Maloney [13] suggested the addition of wax to improve physical properties of particle board. The addition of additive such as wax is used as water repellent, that will make the particle board resistance to water and have high dimensional stability. [14] stated that the addition of $1-5 \%$ wax base on oven dry weight particle can improve dimensional stability properties of composite boards.

TS value after 24 hours of immersion ranged from 4.33 to $6.19 \%$. This value indicated that a zephyr board have good dimensional stability properties compared to 24 hours immersion and maximum standard which about $12 \%$. In contrary with WA properties, TS value of zephyr board classified under maximum standard. The lowest value of TS found in zephyr board made from upper part (4.33\%) whereas the low value of TS caused by addition of phenol formaldehyde resin. Phenol formaldehyde resin have water and humidity resistance properties. Therefore, zephyr board have low value of TS although have high value of WA. Furthermore, [3] also stated that the use of phenol and isocyanate adhesive will produce lower TS value compared to urea formaldehyde and urea-formaldehyde combination with isocyanate resin.

Zephyr strands that produced from different crushed number have significantly different to properties of board, especially MC, density and WA. Petiole palm oil have a lot of phylloderm tissue and have hygroscopic character, when dried it will loosed the bond and easy to absorb water. The processed zephyr board, shrinkage swelling and density properties of petiole changes from $\mathrm{p} 0.27$ to $0.46 \mathrm{~g} . \mathrm{cm}^{-3}$ of density and $205 \%$ of shrinkage swelling to $0.70-0.83$ g.cm ${ }^{3}$ density and $59 \%$ shrinkage swelling of Zephyr board. The performance of zephyr board treated with number of rolling crushed and part of petiole presented in Figure 1 and the performance of zephyr board from different number of rolling crushed presented in Figure 3.

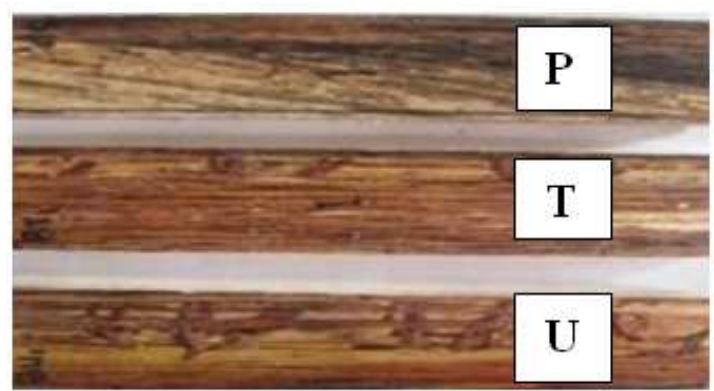

Figure 2. The performance of zephyr board treated with number of rolling crushed and part of petiole P:(base), T: (middle) and U (upper). 


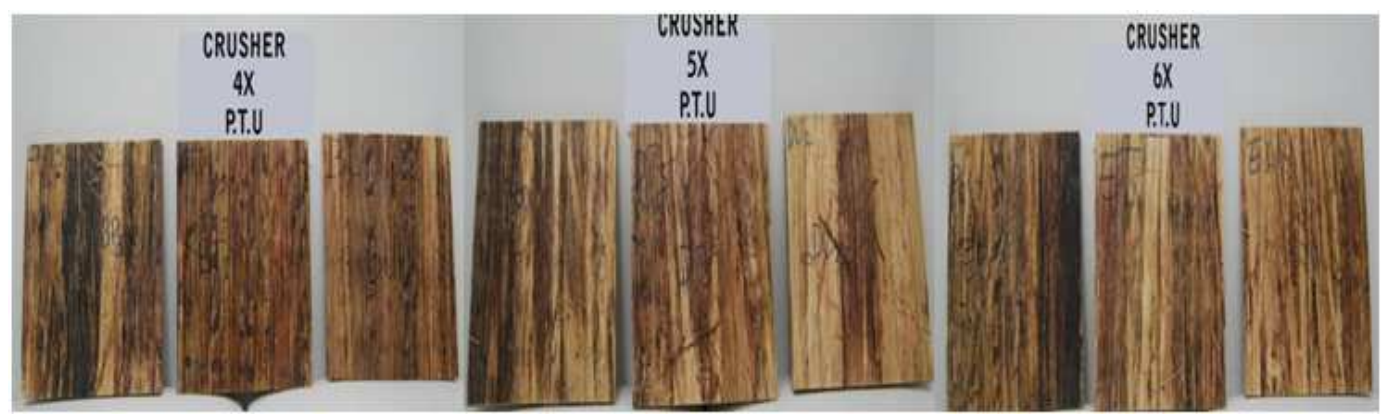

Figure 3. The performance of zephyr board from different number of rolling crushed

\subsection{Mechanical Properties Evaluation}

Evaluation of zephyr boards mechanical properties included MOE, MOR, and SW. Result on mechanical properties of zephyr board is presented in Table 5 .

Table 5. The average value of the MOE, MOR and SW of zephyr board made from petiole palm oil.

\begin{tabular}{lllll}
\hline Treatment & Petiole part & MOE $\left(\mathbf{1 0}^{\mathbf{3}} \mathbf{k g f .} \mathbf{~ c m}^{-\mathbf{2}}\right)$ & MOR $\left(\mathbf{k g f . c m} \mathbf{-}^{-2}\right)$ & SW $\mathbf{( k g f )}$ \\
\hline \multirow{3}{*}{ Crushed 4 times } & Base & 42.7 & 201 & 101.97 \\
& Middle & 32.8 & 250 & 123.74 \\
& Upper & 30.5 & 202 & 90.29 \\
Crushed 5 times & Base & 44.3 & 245 & 91.23 \\
& Middle & 51.2 & 317 & 120.29 \\
& Upper & 56.4 & 277 & 81.10 \\
Crushed 6 times & Base & 35.0 & 248 & 126,63 \\
& Middle & 59.5 & 389 & 110.84 \\
JIS A 5908-2003 Type 18 & Upper & 50.0 & 264 & 119.83 \\
\hline
\end{tabular}

Table 6. The ANOVA value of zephyr board mechanical properties

\begin{tabular}{|c|c|c|c|c|c|c|}
\hline \multirow{2}{*}{ Treatment } & \multicolumn{2}{|c|}{ MOE } & \multicolumn{2}{|c|}{ MOR } & \multicolumn{2}{|l|}{ SW } \\
\hline & $\mathbf{F}$ & $\mathbf{P}$ & $\mathbf{F}$ & $\mathbf{P}$ & $\mathbf{F}$ & $\mathbf{P}$ \\
\hline A(crushed) & 1.22 & $0.318 \mathrm{~ns}$ & 4.20 & $0.032 *$ & 2.67 & $0.097 \mathrm{~ns}$ \\
\hline B (petiole parts) & 0.49 & $0.623 \mathrm{~ns}$ & 4.58 & $0.025^{*}$ & 2.53 & $0.108 \mathrm{~ns}$ \\
\hline $\mathrm{AB}($ Interaction $\mathrm{B})$ & 1.27 & $0.319 \mathrm{~ns}$ & 0.42 & $0.795 \mathrm{~ns}$ & 1.59 & $0.220 \mathrm{~ns}$ \\
\hline check whether is it sd or $\mathrm{SE} \pm$ & \multicolumn{2}{|c|}{$29.76 \%$} & \multicolumn{2}{|c|}{$24.44 \%$} & \multicolumn{2}{|c|}{$39.26 \%$} \\
\hline
\end{tabular}

MOE value of zephyr board varied from 30.5 - 59.5 $\left(\mathrm{x} 10^{3} \mathrm{kgf} \cdot \mathrm{cm}^{-2}\right)$. Zephyr board from middle part treated with 5 times crushed showed the best value compared to others. Result showed little effect of treatments on MOE but the values are with in the optimal changed.sProcesing alm oil petiole into zephyr boards increased MOE value $>20$ times higher than palm oil petiole [12]

MOR of zephyr board varied from of 201-389 kgf. $\mathrm{cm}^{-2}$. The lowest value obtained from base part of petiole treated with 4 times crushed and the highest value obtained from middle part of petiole treated with 6 times crushed. Based on statistical analysis, the number of rolling crushed and part of petiole significantly affected MOR value. Result of DMRT test presented in Table 7.

Based on the crushed $4 \mathrm{x}$ resulted the lowest value and showed have positive correlation with strength of board(Table 6). Middle part of petiole have the maximum value of 120 to $123 \mathrm{kgf}$ as compared to others. Nugroho [3] stated that more homogeneous and smaller zephyr board fiber, produce better board strength. Zephyr made from different petiole part have different fiber homogenity.
Table 7. DMRT test effect of rolling crushed to MOR value of zephyr board

\begin{tabular}{cc}
\hline Roller chruser & MOR \\
\hline $4 \mathrm{x}$ & $210.3 \mathrm{a}$ \\
$5 \mathrm{x}$ & $279.8 \mathrm{~b}$ \\
$6 \mathrm{x}$ & $300.3 \mathrm{~b}$ \\
\hline
\end{tabular}

Description: superscripts followed with different letter indicate significantly different by DMRT at level of $\alpha=0.05$

Table 7. DMRT test effect of petiole part to MOR value of zephyr board

\begin{tabular}{cc}
\hline Part & MOR \\
\hline Base & $228.4 \mathrm{a}$ \\
Middle & $299.3 \mathrm{~b}$ \\
End & $244.5 \mathrm{a}$ \\
\hline
\end{tabular}

Description: superscripts followed with different letter indicate significantly different by DMRT at level of $\alpha=0.05$

SW value range from 76.43 - $126.63 \mathrm{kgf}$. Zephyr boards produced have maximum values as compared to standard $(>500 \mathrm{~N}$ or $>50 \mathrm{kgf}$ ). ANOVA analysis st showed that crushed number and petiole part are not significantly affected SW value. The maximum SW value of $126 \mathrm{kgf}$ 
obtained from 6x crushed. The evaluate of MOR and MOE properties of factor interaction, (number of crushed and petiole part) have big impact to both value. Petiole palm with MOE 1629-4147 kgf.cm ${ }^{2}$ and MOR 64.37 to 110.64 kgf.cm ${ }^{2}$ will produce zephyr board with MOE 30496 $56381 \mathrm{kgf.cm}{ }^{2}$ and MOR 201.29-389.22 kgf.cm².

Number of rolling crushed affected physical properties and MOR of board. Crushed 5 and 6 times were produced more fiber homogenity at of base petiole where it causes fiber broken. Different homogenity of petiole part became one of factor that must be considered when using crusher treatment.

\section{Conclusions}

The study of zephyr board made from different petiole part and number of rolling crushed showed that part of petiole and number of crushed together significantly affect MOR value, whereas physical properties affected by crushed number. Fifth and sixth time crushing was producing more homogenous fiber and the best of zephyr board. In general, the zephyr board was resulting had fulfill JIS A 5908-2003 type 18. Water repellent and petiole pre-treatment was needed to improve properties of zephyr board.

\section{References}

[1] BPS. Badan Pusat Statistik, (2005/2006). Indonesia Statistic. Statistik Beraeu. Jakarta

[2] Yazid I.I., I N. Suastawa, R.P.A.Setiawan.(2005). Physical and mechanical properties of petiole and wood oil palm. Journal of Agriculture Technic.Vol.19.N0.2 Sept 2005. pp $117-126$

[3] Nugroho N. (2001). Development of Processing Methods for Bamboo Composites Materials and Its Structural Performance (Disertation). The University of Tokyo

[4] Gopar M dan Yanni Sudiyani. (2004). The Change of Physical and Mechanical Properties of Zephyr Bamboo Panel after Exposed to Out-door Weathering Prosiding Seminar Ilmiah Hasil-Hasil Penelitian dan Pengembangan Puslitbang Fisika Terapan - LIPI 2003/2004

[5] Nugroho N. and Ando Naoto.(2007). Development of structural composite products made from bamboo I: fundamental properties of bamboo zephyr board, J. Wood Sci., 46, 68-74

[6] Nugroho, $\mathrm{N}$ and Ando Naoto.(2001). Selected properties of full-sized bamboo-reinforced composite beam. In Proc. of Pacific Timber Engineering Conference, 14-18 march 2001. Roturua, New-Zealand. Vol.3:455-458.

[7] Lee, Min-Jay Chung, Chih-Hsien Lin, Te-Hsin Yang. (2012). Effects of layered stucture on the physical and mechanical properties of laminated moso bambo (Phyllosachys edulis) flooring. Construction and Building Materials, Volume 28, Issue 1, March 2012, Pages 31-35

[8] Kim,Y.J, M.Okuma and T.Yokota .1998. A study on Sheet material made from Zephyr StrandsV : Properties of Zephyr Strands Board and Zephyr Strand Lumber using veneer of fast growing species such as Poplar.J.Wood Sci. Vol44 No.6:438-443

[9] Gopar and Y Sudiyani.(2004). Exchanged Physical and Mechanical Properties Zephyr Board After Weathering Treatment. Journal Technology and Science Of Tropical Wood 4(1): 28-32

[10] Lusita W, M Y. Masiijaya, YS Hadi, IW Darmawan. (2012). Anatomical and Chemical Petiole of Oil Palm Properties. Proceedings of The Fourth International Symposium of IwoRS, Makasar, 7-8 November 2013.pp.16-21

[11] JIS. Japanese Standards Association.(2003). Particleboards. Japanese Industrial Standards (JIS) A 5908-1994, Japan

[12] Lusita Wardani, MY Massijaya,YS Hadi, IW Darmawan.(2012). Papan Zephyr dari pelepah sawit, Prosiding Mapeki XV Makasar. 6 Nov 2012.

[13] Maloney TM. (1993). Modern Particleboard and Dry Process Fiberboard Manufacturing. San Fransisco: MILLER Freeman, Inc.

[14] Erniwati, Yusuf Sudo Hadi, Muh.Yusram Massijaya, Naresworo Nugroho.(2006). The Quality of the composite board with bamboo layers(II): Utilization of paraffin at several levels. Jurnal Teknologi Hasil Hutan. Fakultas Kehutanan IPB. Vol 19 No.1 Tahun 2006, pp;32-39

[15] Gopar M and Y Sudiyani.(2004). Exchanged Physical and Mechanical Properties Zephyr Board After Weathering Treatment. Journal Technology and Science Of Tropical Wood 4(1): 28-32

[16] Khandkar-Siddikur Rahman, Nazmul Alam D.M.1 and Md. Nazrul Islam.(2012). Some Physical and Mechanical Properties of Bamboo Mat-Wood Veneer Plywood ISCA Journal of Biological Sciences ISSN 2278-320

[17] Nurul Aini S, K Bintani,A Haris.(2008). Papan partikel dari pelepah sawit. Loka Perintisan Bahan Bangunan Lokal Cilacap. 2 Vol.1(2). 61-64, June 2012

[18] Sukma S Kusumah, Ruslan.M.Daud, Ika Wahyuni, Teguh D, Yusup A, Muh.Yusram Massijaya, B.Subiyanto,(2011). Pengembangan papan komposit dari limbah perkebunan Sagu (Metroxylon sago Rottb). Prosiding MAPEKI IV Yogyakarta, 2 Nov 2011

[19] Sumardi I., Ono K. and Suzuki S. (2007). Effect of board density and layer structure on the mechanical properties of bamboo oriented strand board, J. Wood Sci., 53, 510-515

[20] Sudiyani and Subyakto. (2005). Physical and Mechanical properties of zephyr board made from gombong bamboo. Procedings of the fourth international wood science symposium I.Bogor, November 2005.pp 65-71 